\title{
Galectin-1 as a Multifunctional Molecule in the Peripheral Nervous System After Injury
}

\author{
Kazunori Sango ${ }^{1}$, Hiroko Yanagisawa ${ }^{1}$, Kazuhiko Watabe ${ }^{1}$, \\ Hidenori Horie ${ }^{2}$ and Toshihiko Kadoya ${ }^{3}$ \\ ${ }^{1}$ ALS/Neuropathy Project, \\ Tokyo Metropolitan Institute of Medical Science \\ ${ }^{2}$ Research Center of Brain and Oral Science, \\ Kanagawa Dental College \\ ${ }^{3}$ Department of Biotechnology, \\ Maebashi Institute of Technology \\ Japan
}

\section{Introduction}

Restoration from peripheral nerve injury requires both neuronal cell survival and axonal regeneration across the site of injury and along the distal nerve stump as well as functional reconnection with the appropriate targets. It is no doubt that the concerted interplay of regenerating axons, non-neuronal cells (e.g. Schwann cells and macrophages), neurotrophic factors and cytokines, cell adhesion molecules, and extracellular matrix components is essential for successful nerve regeneration (Zochodne, 2008). A plenty of molecules have been implicated in the regenerative response to nerve injury (Terenghi, 1999; Yasuda et al., 2003) and the therapeutic approaches using the delivery systems for the target genes have been receiving increasing attention (Mason et al., 2011); however, the signals that prompt neurons to extend processes in peripheral nerves after injury are not fully understood.

We have established three-dimensional collagen gel culture system of ganglion explants, in which adult peripheral ganglia (mainly dorsal root ganglia (DRG)) with nerve fibers are embedded in collagen gel and the number and length of regenerating neurites from nervetransected terminals are measured under a phase-contrast microscope (Fig.1, right; reproduced from Sango et al., 2006). Since the cell-cell interactions are maintained in the explanted ganglia, it is fair to state that the explant culture system mimics nerve regeneration in vivo better than the dissociated cell culture system (Fig.1, left). By employing the explant models, we showed that various kinds of neurotrophic factors (Horie et al., 1991a; Akahori et al., 1997), cytokines (Horie et al., 1997; Shuto et al., 2001), co-cultured tissues (Horie et al., 1991b; Saito et al., 2002) and experimental diabetes (Saito et al., 1999; Sango et al., 2002) enhanced neurite regeneration. 


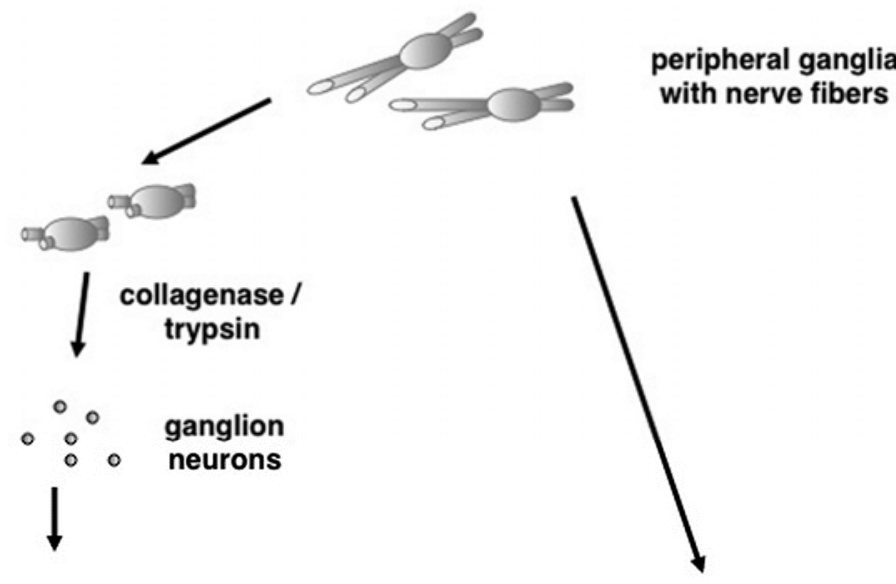

dissociated cell culture

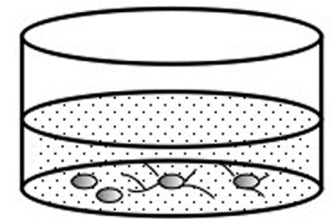

explant culture

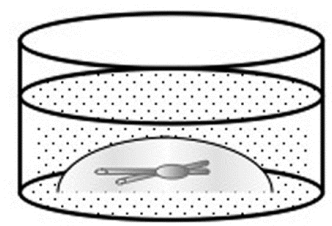

Fig. 1. Schematic representation of the methods for dissociated cell culture and explant culture of peripheral ganglia. In the former, each of the ganglion neurons is mechanically and enzymatically isolated, and seeded onto culture dishes precoated with extracellular substrate(s). In the latter, peripheral ganglia with nerve fibers are embedded in collagen gel. The number and length of regenerating neurites from nerve-transected terminals are measured under a phase-contrast microscope (Reproduced from Sango et al., Current Diabetes Reviews, 2006, Vol.2, No.2, pp.169-183, with permission from Bentham Science Publishers Ltd.).

Furthermore, we searched for novel axonal regeneration-promoting factors from the culture supernatants of COS1 cells (a cell line derived from the kidneys), and purified the protein with molecular weight of around $14 \mathrm{kDa}$. The analysis of the internal amino acid sequences of the active protein indicated that it was identical to galectin-1 (GAL-1) (Horie et al., 1999). GAL-1 is a member of the galectins, a family of $\beta$-galactoside binding animal lectin (Barondes et al., 1994) and has been shown to play roles in a wide variety of biological functions such as cell growth and differentiation, apoptosis, cell adhesion, tumor spreading, and inflammatory response (Camby et al., 2006; Rabinovich et al., 2007). Most of the studies on the biological activities of GAL-1 were performed under reducing conditions, and the effects of GAL-1 were inhibited by lactose. However, the $14 \mathrm{kDa}$ protein secreted from COS1 cells exists as an oxidized form of GAL-1 (GAL-1/Ox), containing three intramolecular disulfide bonds (Cys 2 -Cys ${ }^{130}$, Cys ${ }^{16-}{ }_{-}$ys $^{88}$, and $\mathrm{Cys}^{42}-\mathrm{Cys}^{60}$ ) as shown in Fig. 2. (reproduced from Kadoya \& Horie, 2005).

In contrast to the concept that GAL-1 is biologically active only in the reduced form, we introduced GAL-1/Ox as a novel factor enhancing axonal regeneration in peripheral nerves 
(Inagaki et al., 2000; Horie et al., 1999, 2004, 2005). The potent activity of recombinant human GAL-1/Ox on axonal regeneration has been confirmed by several in vivo experiments (Horie et al., 1999; Fukaya et al., 2003; Kadoya et al., 2005).
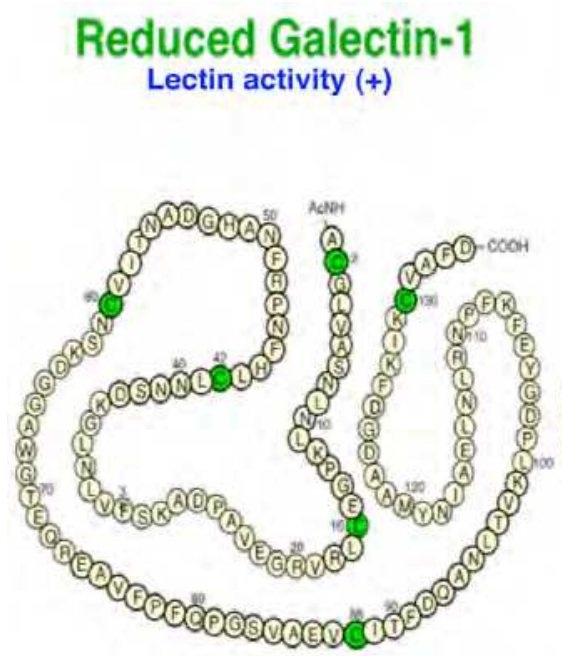

Oxidized Galectin-1 Lectin activity $(-)$ Axonal regenerationpromoting activity ( + )

Fig. 2. Bubble map of reduced and oxidized GAL-1. GAL-1 having -galactoside-binding activity exists in a reduced form, whereas oxidized GAL-1 contains three intramolecular disulfide bonds (Reproduced from Kadoya \& Horie, Current Drug Targets, 2005, Vol.6, No.4, pp. 375-383, with permission from Bentham Science Publishers Ltd.)

The growing evidence suggests that both reduced and oxidized forms of GAL-1 are involved in the repair process after nerve injury (Camby et al., 2006), but there is a marked difference in the structural and functional properties between the two forms; GAL- 1 in the reduced form acts on nervous tissue as a lectin (Sasaki et al., 2004; Plachta et al., 2007), whereas GAL-1/Ox lacks lectin activity and acts as a cytokine-like molecule (Horie et al., 1999; Inagaki et al., 2000; Kadoya et al., 2005). In this chapter, we further characterize GAL-1 as a multi-functional molecule in the peripheral nervous system, focusing on its distribution, regulation of synthesis, extracellular release and oxidation, and possible action mechanisms for neuroprotection and axonal regeneration after injury.

\section{Localization of GAL-1 in the peripheral nervous system}

GAL-1 is encoded by the LGALS1 gene located on the human chromosome 22q13.1. The $0.6 \mathrm{~kb}$ transcript results from the splicing of four exons and encodes for a protein of 135 amino acids. It exists as a monomer as well as a non-covalent homodimer with a subunit molecular weight of $14.5 \mathrm{kDa}$ (Barondes et al., 1994; Sango et al., 2004). GAL-1 is highly expressed in peripheral nervous tissues of adult rodents, with immunoreactivity localized to cell bodies of sensory and motoneurons, axons and Schwann cells (Fukaya et al., 2003; Akazawa et al., 2004). GAL-1 mRNA persists in DRG neurons at later developmental stages and is maintained in adult DRG neurons. Using in situ hybridization histochemistry, GAL-1 mRNA has been detected in nearly all neurons of the DRG. In general, the staining intensity in smaller diameter $(<30 \mu \mathrm{m})$ neurons 
was higher than that in larger diameter neurons (Sango et al., 2004). The small DRG neurons are reported to have small myelinated (A $\delta$ ) and unmyelinated (C) fibers, which can play an essential role in thermoreception and nociception; whereas the large neurons have large myelinated $(\mathrm{A} \beta)$ fibers and are known to be mostly sensitive mechenoreceptors (Salt \& Hill, 1983). Therefore, predominant expression of GAL-1 mRNA/protein in subpopulations of small diameter neurons (Regan et al., 1986, Hynes et al., 1990, Imbe et al., 2003, Sango et al., 2004, McGraw et al., 2005a) suggests that this molecule is involved in the transmission of nociceptive and thermoceptive information. In fact, mice lacking GAL-1 showed reduced sensitivity to noxious thermal stimuli (McGraw et al., 2005b).

\subsection{Predominant expression of GAL-1 in small IB4-binding DRG neurons in vivo}

Adult DRG neurons can be broadly divided into three principal subgroups by their soma size and characteristic markers (Fig.3; modified from McMahon \& Bennett, 2000):

1. large neurons; immunoreactive for $200 \mathrm{kD}$ neurofilaments (NF200),

2. small peptidergic neurons; immunoreactive for calcitonin gene-related peptide (CGRP) and high-affinity NGF receptor (trkA), and

3. small non-peptidergic neurons; immunoreactive for GDNF receptors (Ret, GFR $\alpha$ ) and binding to isolectin B4 (IB4).

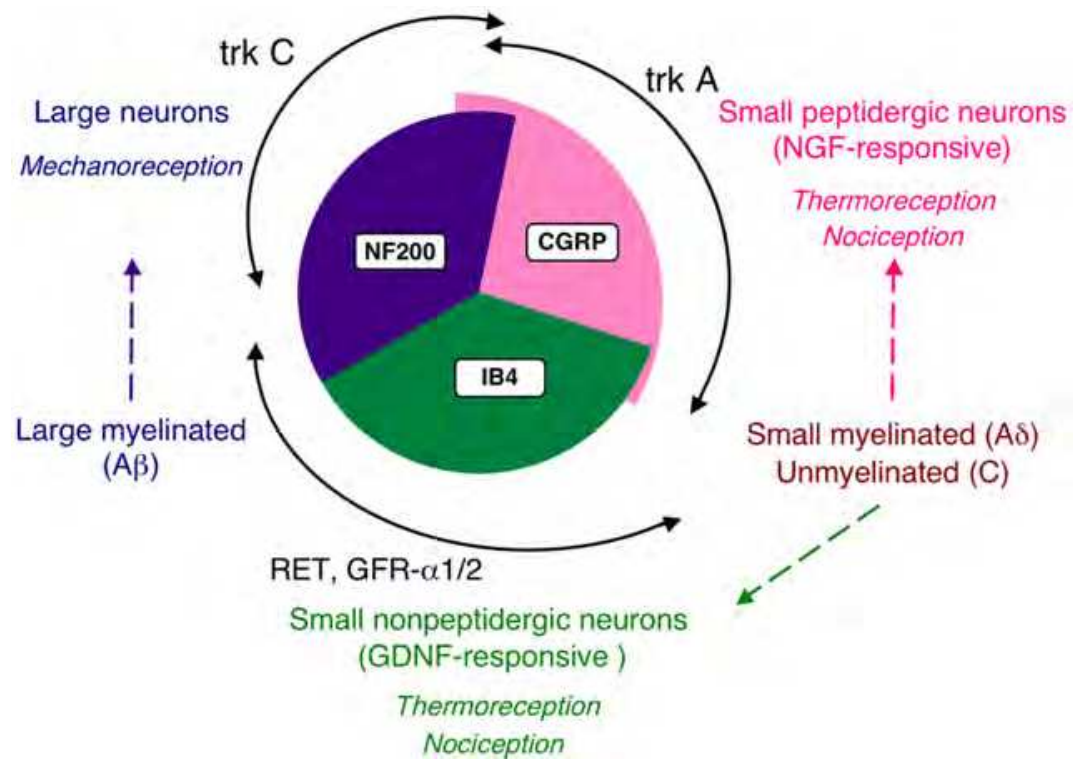

Fig. 3. Three principal subgroups of adult DRG neurons. Large neurons, immunoreactive for $200 \mathrm{kDa}$ neurofilament, are known to possess large myelinated fibers. Small neurons are divided into peptidergic and non-peptidergic neurons; peptidergic neurons are immunoreactive for CGRP and high affinity NGF receptor trkA, whereas non-peptidergic neurons bind the lectin IB4 and express GDNF receptors. Both groups of small neurons are known to possess small myelinated and unmyelinated fibers (modified from McMahon \& Benette, Molecular Basis of Pain Induction, 2000, pp. 65-86, with permission from John Wiley \& Sons, Inc.). 
Both small peptidergic and non-peptidergic neurons are responsible for the transmission of nociception and thermoreception, and whether these two groups of neurons have distinct functions has been the subject of controversy (McMahon \& Bennett, 2000; Ernsberger, 2009).
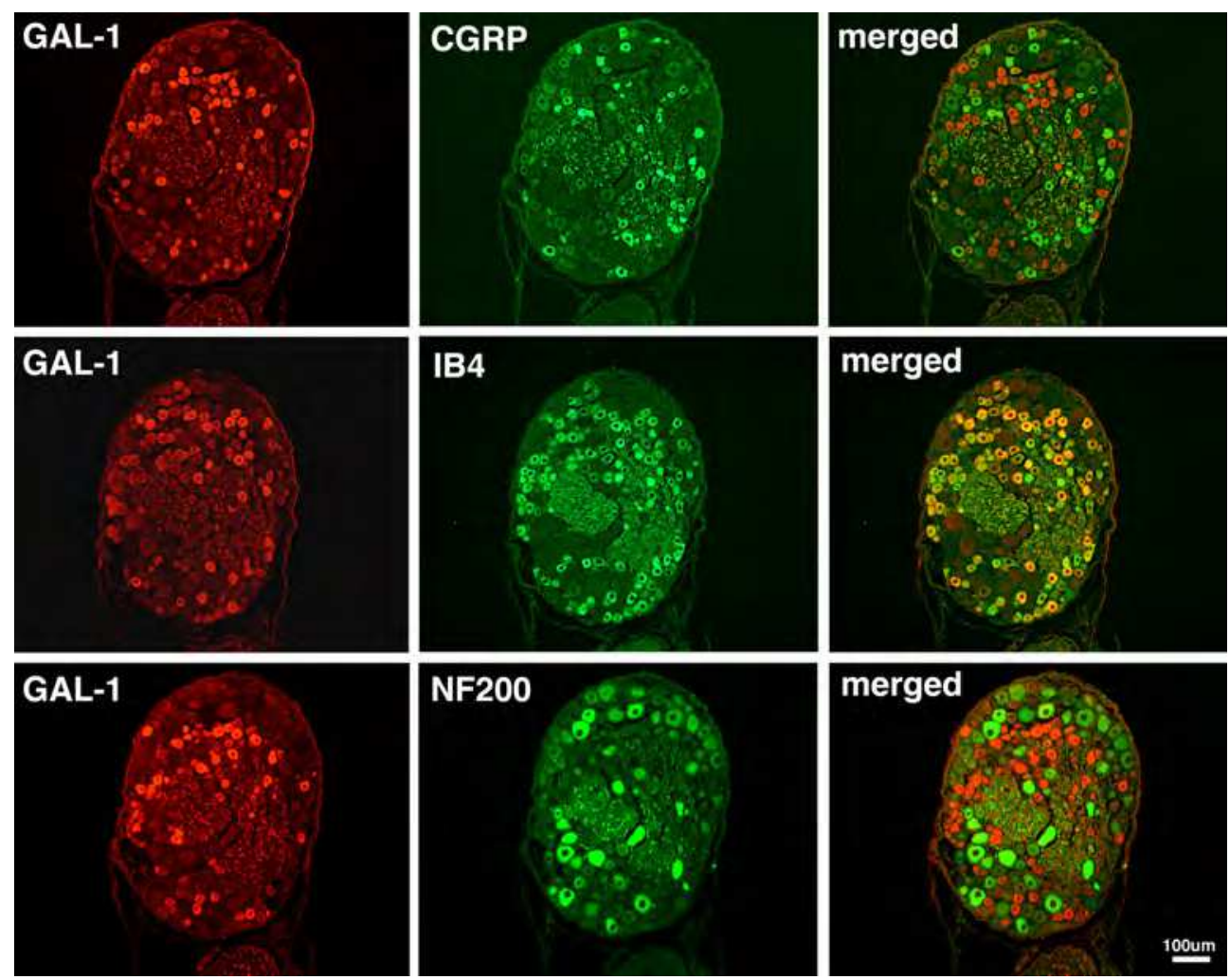

Fig. 4. Predominant expression of GAL-1 in small non-peptidergic neurons of adult rat DRG. Immunofluorescence micrographs of adult rat DRG sections, stained with antibodies to GAL-1 (red) and CGRP, IB4, or NF200 (green). The merged pictures are on the right. Almost all GAL-1 intensely labeled neurons are IB4-binding neurons, and distinguished from CGRP intensely labeled neurons and NF200 intensely labeled neurons.

Our immunohistochemical analysis revealed intense immunoreactivity for GAL-1 in a subset of small diameter neurons in the sections of adult rat lumbar DRG (Fig.4, left). The ratio of GAL-1-immunoreactive (IR) neurons was 31.6 $\pm 5.4 \%$ (mean \pm SD from nine sections, 1717 neurons from three animals). By double immunofluorescent staining, $96.5 \pm 1.3 \%$ of the GAL-1IR neurons were IB4-binding, whereas $3.7 \pm 1.2 \%$ and $0 \%$ were CGRP-IR and NF200-IR, respectively (Fig.4, center and right). These findings agree with the previous study by Imbe et al. (2003); they performed immunohistochemistry and in situ hybridization using two pairs of consecutive sections of lumbar DRG, and observed that $93.9 \%$ and $6.8 \%$ of the intensely GAL1-IR neurons displayed mRNA for c-RET and trkA, respectively. On the other hand, the double immunofluorescent staining with the sections of cervical DRG (McGraw et al., 2005a) 
showed that $33 \%$ and $28 \%$ of the GAL-1-IR neurons were IB4-binding and CGRP-IR. Such differences may arise from variations in the distribution of GAL-1 at different spinal levels and/or different evaluation of the intensity for GAL-1-IR among the investigators. The finding that mice lacking GAL-1 showed reduced proportion of IB4-binding DRG neurons (McGraw et al., 2005b) indicates the involvement of GAL-1 in the proper phenotypic differentiation of the non-peptidergic DRG neurons during development.

\subsection{GDNF upregulates protein expression of GAL-1 in cultured DRG cells}

Our immunohistochemical analyses revealed that almost all the GAL-1 intensely stained DRG neurons were IB4-binding small non-peptidergic neurons (Figs.3\&4). Since NGF and GDNF are likely to exert their major effects on small peptidergic and non-peptidergic neurons, respectively (Molliver et al., 1997), it seems plausible that GDNF regulates synthesis and/or distribution of GAL-1 in non-peptidergic DRG neurons. Following peripheral axotomy, GAL-1 expression was downregulated in small DRG neurons but was upregulated in NF200-IR large neurons (Imbe et al., 2003; McGraw et al., 2005a). These findings imply that retrogradely transported NGF and/or GDNF play a role in the dominant expression of GAL-1 in small DRG neurons (Lindsay \& Harmar, 1989; Bennett et al., 1998).

By employing the dissociated cell culture model (Fig.1, left), we examined the effects of recombinant NGF and GDNF on neurite outgrowth and GAL-1 expression in adult rat DRG. As shown in previous studies (Lindsay, 1988; Gavazzi et al., 1999; Sango et al., 2008), both NGF and GDNF promoted neurite outgrowth from small DRG neurons (Fig.5).
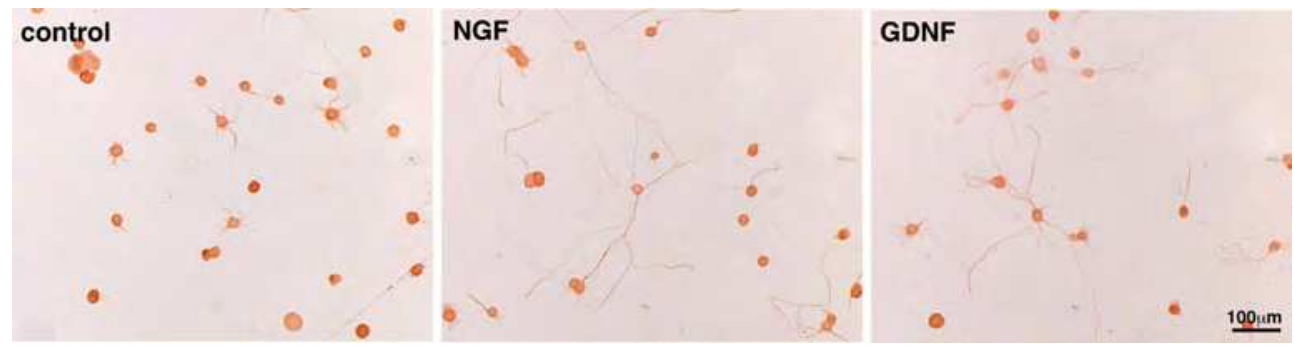

Fig. 5. Adult rat DRG neurons after 2 days in culture were immunostained with anti- $\beta$ III tubulin. An application of NGF or GDNF to culture medium $(50 \mathrm{ng} / \mathrm{ml})$ enhanced neurite outgrowth, and their effects were small neuron-dominant.

Immunocytochemical analysis showed intense GAL-1-IR in almost all neurons from a very early stage $(3 \mathrm{~h})$ to an end of the observation period (> 7 days) in culture in the absence of NGF or GDNF (Fig.6). This finding is in contrast to the predominant expression of GAL-1 in small non-peptidergic neurons in vivo. Enzymatic and mechanical treatments for the dissociation of DRG cells, together with disruption of interactions between neurons and non-neuronal cells are detrimental to neurons. Therefore, GAL-1 expressed in cultured neurons may function as a stress marker protein (Iwamoto et al., 2010) and/or a cytoprotective molecule (Lekishvili et al., 2006) during in vivo-in vitro replacement. 


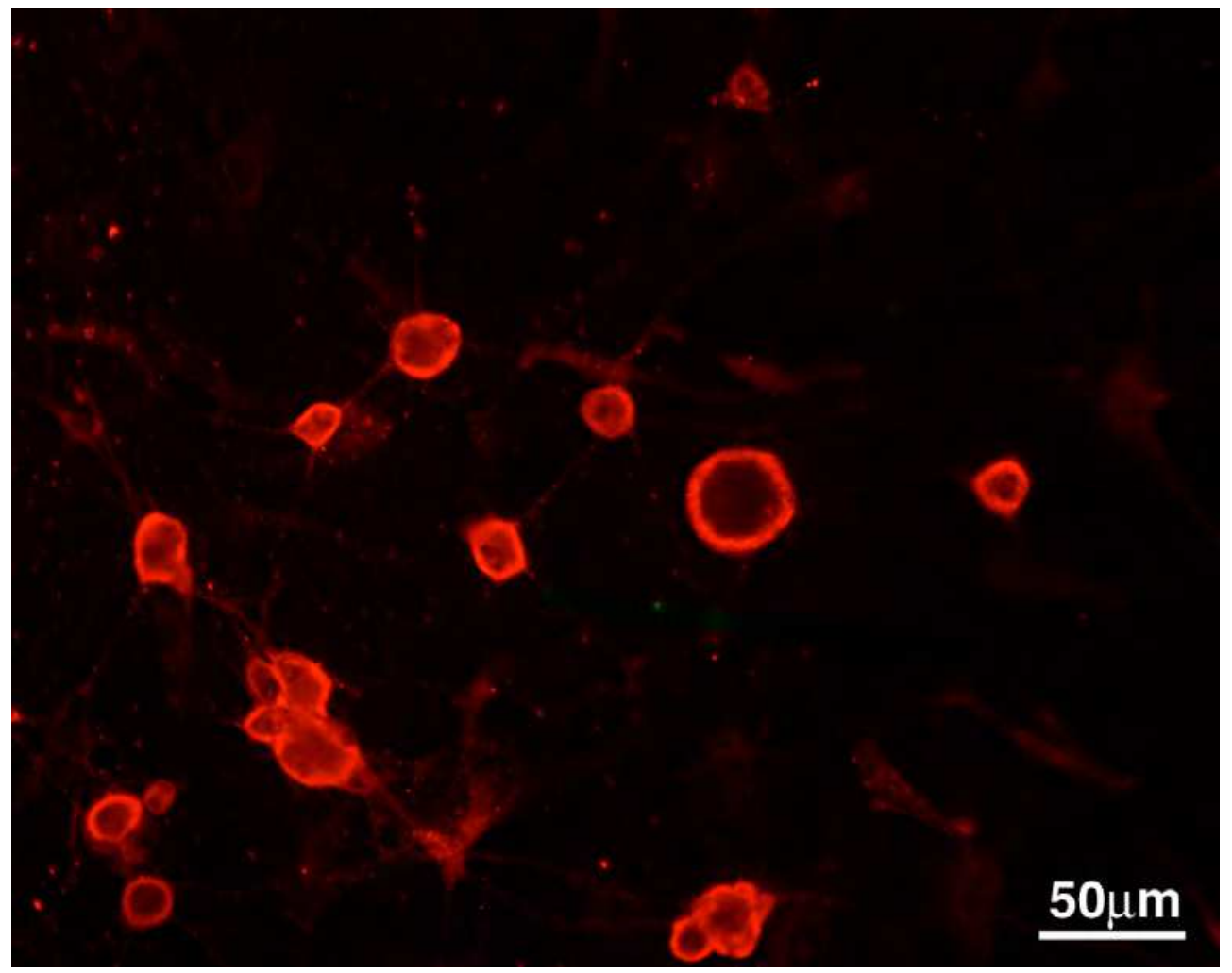

Fig. 6. Immunohistochemical localization of GAL-1 in adult rat DRG neurons after 5 days in culture. Intense GAL-1 immunoreactivity was observed at the surface of almost all neurons.

\section{control NGF GDNF}

\section{GAL-1}

\section{$\beta$-actin}

Fig. 7. GDNF, but not NGF, upregulates the expression of GAL-1 in cultured DRG cells: Western blot analysis. The neuron-enriched culture of DRG $12 \mathrm{~h}$ after seeding was incubated with serum-free medium containing $50 \mathrm{ng} / \mathrm{ml}$ of NGF or GDNF for $36 \mathrm{~h}$. 
The abundant expression of GAL-1 in cultured DRG neurons under the basal conditions (Ham's H12 / B27 supplement in the absence of NGF or GDNF) made it difficult to evaluate the effects of NGF or GDNF on the GAL-1-IR by immunocytochemistry. Then we prepared the neuron-enriched DRG culture $\left(>5 \times 10^{3}\right.$ cells $/ \mathrm{cm}^{2}$ at seeding) for Western blot analysis as previously described (Sango et al., 2007). The blot showed that GDNF, but not NGF, upregulated protein expression of GAL-1 (Fig.7). This finding suggests that GAL-1 is one of the downstream target molecules of GDNF in cultured DRG neurons. Our current study is aimed at elucidating the signaling molecules and pathways involved in the GDNF-induced neurite outgrowth and upregulation of GAL-1 (Sango et al., in preparation).

\section{Externalization of GAL-1 from neurons and Schwann cells}

Despite lacking a signal leading peptide, GAL-1 is subject to externalization via non-classical pathway from various kinds of cells (Cooper \& Barondes, 1990; Avellana-Adalid et al., 1994; Hughes, 1999). Our immunocytochemical and Western blot analyses showed the externalization of GAL-1 from primary cultured adult rat DRG neurons and Schwann cells, and immortalized adult mouse Schwann cells IMS32 (Watabe et al., 1995; Sango et al., 2004). In addition to these cells, we have recently established spontaneously immortalized Schwann cell lines from long-term cultures of adult Fischer 344 rat DRG and peripheral nerves. One of these cell lines, designated IFRS1, showed distinct Schwann cell phenotypes, such as spindle-shaped morphology under phase-contrast microscopy (Fig.8A), intense immunoreactivity for Schwann cell markers (e.g. S100 and p75 low affinity neurotrophin receptor(p75NTR)), mRNA expression for neurotrophic factors (NGF, GDNF, CNTF), cell adhesion molecules (L1, NCAM, N-cadherin), transcription factors (Sox10, Oct6, Krox20) and myelin proteins (P0, PMP22, MAG)(Sango et al., 2011). Moreover, IFRS1 cells are capable of myelinating neurites in coculture with adult rat DRG neurons (Sango et al., 2011) and NGFprimed PC12 cells (Sango et al., submitted). We observed the intense immunoreactivity for GAL-1 in the cell bodies and processes of IFRS1 cells (Fig.8B). Further, Western blot analysis revealed the intense immunoreactivity for GAL-1 in both IFRS1 cells and culture medium (supernatant) (Fig.8C). These findings suggest that IFRS1 cells synthesize and secrete GAL-1, in a similar manner to DRG neurons and IMS32 cells (Sango et al., 2004).

Following externalization, some of the galectin molecules are suggested to associate with surface or extracellular matrix glycoconjugates where lectin activity is stabilized, whereas the others free from glycoconjugate ligands are rapidly oxidized in the non-reducing extracellular environment (Tracey et al., 1992).
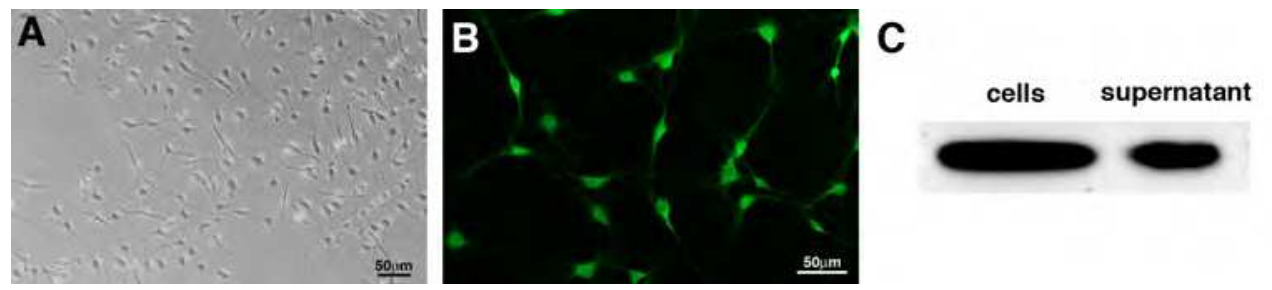

Fig. 8. Localization and externalization of GAL-1 in immortalized adult rat Schwann cells IFRS1. (A) A phase-contrast micrograph of IFRS1 cells. (B) Immunocytochemical localization of GAL-1 in IFRS1 cells. (C) Western blot analysis of IFRS1 cells and supernatant for GAL-1. 


\section{Biological roles of GAL-1 in the nervous tissue after injury}

As described above, GAL-1 exists in both an oxidized and reduced state and only shows the lectin activity in its reduced state. Several studies have been conducted on the bioactivity of the reduced form of GAL-1 on the nervous tissue after injury, whereas we have been focusing on the axonal regeneration-promoting activity of GAL-1/Ox.

\subsection{GAL-1 in the reduced form}

The bioactivity of recombinant reduced GAL-1 was examined in vitro. When used as a coating substrate, it promoted adhesion, aggregation and neurite fasciculation of newborn rat DRG neurons (Outenreath \& Jones, 1992) and olfactory neurons (Mahanthappa et al., 1994; Puche et al., 1996). In contrast, however, we saw no significant effects of GAL-1 on adhesion or neurite outgrowth of adult rat DRG neurons (Sango et al., unpublished data). When applied to culture medium, it induced differentiation of primary cultured rat cerebellar astrocytes and production of brain-derived neurotrophic factor (BDNF) (Sasaki et al., 2004; Endo, 2005). Since these changes were inhibited by lactose, the lectin activity of GAL-1 appears to be essential for the induction of astrocyte differentiation. These findings suggest that GAL-1 in the reduced form is involved in the neuroprotective function via acting on astrocytes after brain injury.

Using embryonic stem cell-derived neurons engineered with a p75NTR cDNA, Plachta et al. (2007) identified GAL-1 in the reduced form as an inducible factor for the degeneration of neuronal processes. They also showed the delayed elimination of peripheral nerve endings after sciatic nerve injury in GAL-1 deficient mice. These finding suggest that GAL-1 play a major role in the process of Wallerian degeneration and subsequent functional reinnervation after peripheral nerve injury.

\subsection{GAL-1 in the oxidized form (GAL-1/Ox)}

The bioactivity of recombinant GAL-1/Ox was initially evaluated by DRG explant culture models, as shown in Fig.1. GAL-1/Ox did not show the lectin activity, but enhanced neurite outgrowth from transected nerve terminals of DRG explants in a dose-dependent manner (pg/ml range). We prepared a GAL-1 mutant CSGAL-1, in which all six cysteine residues were replaced by serine. CSGAL-1 did not promote neurite outgrowth, but showed lectin activity even under non-reducing conditions (Inagaki et al., 2000). These findings indicate that the axonal regeneration-promoting activity of GAL-1/Ox is unrelated to its lectin properties.

In stark contrast to the neurotrophic factors (e.g. NGF, GDNF, and CNTF), recombinant GAL-1/Ox does not directly work on isolated DRG neurons to promote neurite outgrowth (Horie et al., 1999, 2005; Inagaki et al., 2000). Application of fluorescence-conjugated GAL1/Ox to DRG neurons, Schwann cells, and peritoneal macrophages, showed that only the surface of macrophages was clearly labeled (Horie et al., 2004). This finding suggests that macrophages are a target cell of GAL-1/Ox. Consistently, recombinant GAL-1/Ox induced tyrosine phosphorylation of proteins in macrophages. Furthermore, conditioned medium from GAL-1/Ox-stimulated macrophages enhanced neurite regeneration and Schwann cell 
migration from DRG explants greater than that from non-activated macrophages. These findings suggest that GAL-1/Ox binds to macrophages to activate their signal transduction pathways and secrete some neurotrophic molecules. Taking these findings together with those described above, we proposed a possible action mechanism of GAL-1/Ox for the promotion of axonal regeneration after injury (Fig.9). First, cytosolic GAL-1 is released from growing axons and Schwann cells into the extracellular space upon axonal injury. Next, some of the molecules in the extracellular milieu is converted to the oxidized form (GAL1/Ox). Finally, GAL-1/Ox stimulates macrophages to release some neurotrophic molecules, which in turn enhance neurite regeneration and Schwann cell migration. This hypothesis will be further strengthened by identification of specific receptors for GAL-1/Ox on the macrophages and neurotrophic molecules secreted from macrophages. A recent study by Echigo et al. (2010) showed that GAL-1/Ox acts on the macrophage cell line RAW264.7 to induce phosphorylation of extracellular signal-regulated protein kinase $1 / 2$ (ERK1/2). This cell line can be a valuable tool for the elucidation of the precise mechanisms underlying the promotion of axonal regeneration by GAL-1/Ox.

\section{Neurons, Schwann cells $\quad$ Extracellular Space}

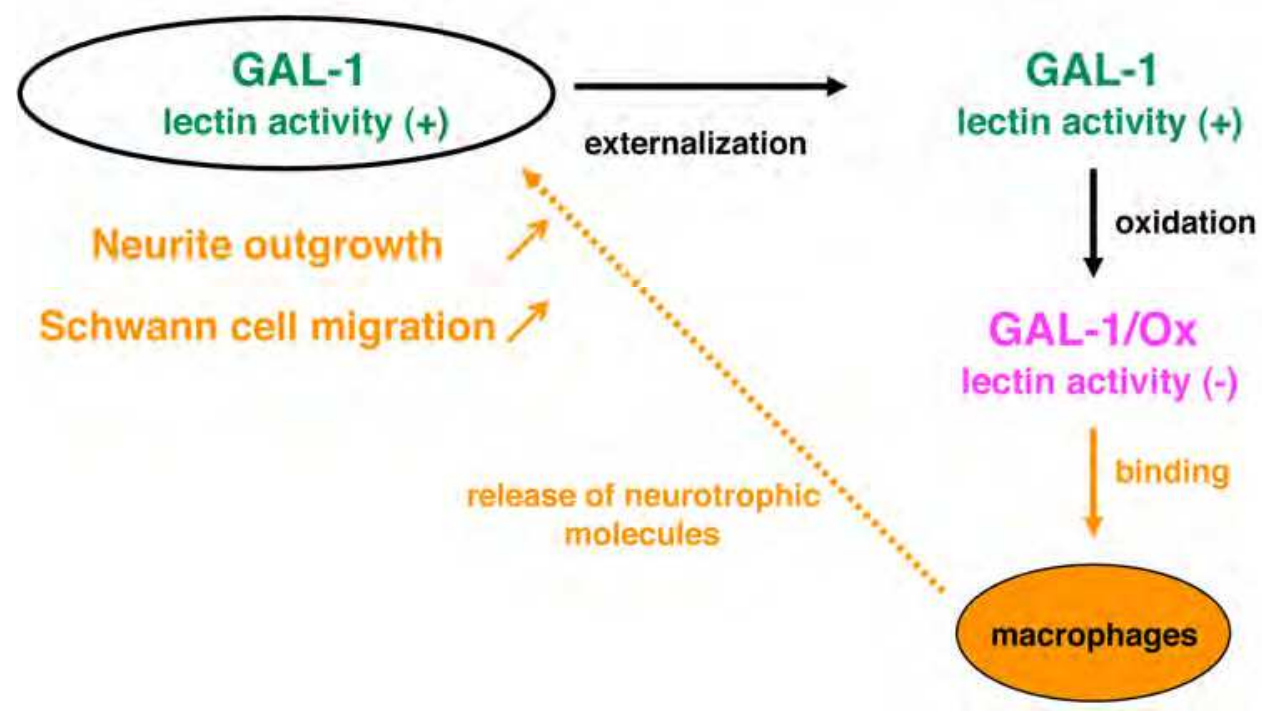

Fig. 9. A possible action mechanism of GAL-1 for the promotion of axonal regeneration. Some of the GAL-1 molecule released from neurons and Schwann cells are converted to the oxidized form with intramolecular disulfide bonds, which lacks lectin activity but could promote axonal regeneration and Schwann cell migration via activating macrophages.

Gaudet et al. (2009) precisely investigated a role for GAL-1 in the accumulation of macrophages following peripheral nerve injury. They observed that the axotomy-induced accumulation of macrophages in normal mouse sciatic nerve distal to ligation was inhibited 
by injection of anti-GAL-1 antibody. Consistently, mice lacking GAL-1 exhibited delayed and diminished macrophage accumulation by sciatic nerve injury. Further, injection of GAL-1/Ox into uninjured sciatic nerve enhanced the accumulation of macrophages in normal mice. These findings indicate the implication of GAL-1/Ox, as well as GAL-1 in the reduced from (Plachta et al., 2007), in the prompt response of macrophages to nerve injury, which is essential for Wallerian degeneration.

\section{Conclusion}

Since we introduced GAL-1/Ox as a novel axonal regeneration-promoting factor after injury (Horie et al, 1999), a considerable number of studies have been made on the biological properties of GAL-1 in the nervous system. GAL-1 is a multifunctional protein and plays different roles dependent on whether it is in the reduced or oxidized form. It is noteworthy that both reduced and oxidized forms of GAL-1 participate in the process of Wallerian degeneration (Plachta et al., 2007; Gaudet et al., 2009), although the precise mechanisms underlying it remain unclear. The growing evidence from both in vivo and in vitro studies suggests that GAL-1/Ox may be useful as a novel therapeutic agent for functional restoration after peripheral nerve injury.

\section{Acknowledgement}

This study was supported by a Grant-in-aid for Scientific Research, from the Ministry of Education, Science, Sports and Culture, Japan, and by the Umehara Fund, Yokohama, Japan. We thank Drs. Yusaku Nakabeppu, Hitoshi Kawano, Nobuaki Maeda and Shizuka Takaku for helpful suggestions, Hiroko Ueda and the late Kyoko Ajiki for technical assistance, and Bentham Science Publishers Ltd. and John Wiley \& Sons, Inc. for permission to reproduce the illustrations.

\section{References}

Akahori, Y. \& Horie, H. (1997). IGF-I enhances neurite regeneration but is not required for its survival in adult DRG explant. Neuroreport, Vol.8, No.9-10, (July 1997), pp. 22652269, ISSN 0959-4965

Akazawa, C.; Nakamura, Y.; Sango, K.; Horie, H. \& Kohsaka, S. (2004). Distribution of the galectin-1 mRNA in the rat nervous system: its transient upregulation in rat facial motor neurons after facial nerve axotomy. Neuroscience, Vol.125, No.1, (March 2004), pp. 171-178, ISSN 0306-4522

Avellana-Adalid, V.; Rebel, G.; Caron, M.; Cornillot, J.D.; Bladier, D. \& Joubert-Caron, R. (1994). Changes in S-type lectin localization in neuroblastoma cells (N1E115) upon differentiation. Glycoconjugate Journal, Vol.11, No.4, (August 1994), pp. 286-291, ISSN 0282-0080

Barondes, S.H.; Castronovo, V.; Cooper, D.N.W.; Cummings, R.D.; Drickamer, K.; Feizi, T.; Gitt, M.A.; Hirabayashi, J.; Hughes, C.; Kasai, K.; Leffler, H.; Liu, F.; Lotan, R.; Mercurio, A.M.; Monsigny, M.; Pillai, S.; Poirer, F.; Raz, A.; Rigby, P.W.J. \& Wang, J.L. (1994). Galectins; a family of animal ß-galactoside-binding lectins. Cell, Vol.76, No.4, (February 1994), pp.597-598, ISSN 0092-8674 
Bennett, D.L.; Michael, G.J.; Ramachandran, N.; Munson, J.B.; Averill, S.; Yan, Q.; McMahon, S.B. \& Priestley, J.V. (1998). A distinct subgroup of small DRG cells express GDNF receptor components and GDNF is protective for these neurons after nerve injury. The Journal of Neuroscience, Vol.18, No.8, (April 1998), pp. 30593072, ISSN 0270-6474

Camby, I.; Le Mercier, M.; Lefranc, F. \& Kiss, R. (2006). Galectin-1: a small protein with major functions. Glycobiology, Vol.16, No.11, (July 2006), pp. 137R-157R, ISSN 09596658

Cooper, D.N. \& Barondes, S.H. (1990). Evidence for export of a muscle lectin from cytosol to extracellular matrix and for a novel secretory mechanism. Journal of Cell Biology, Vol.110, No.5, (May 1990), pp. 1681-1691, ISSN 0021-9525

Echigo, Y.; Sugiki, H.; Koizumi, Y.; Hikitsuchi, S. \& Inoue, H. (2010). Activation of RAW264.7 macrophages by oxidized galectin-1. Immunology Letters, Vol.131, No.1, (January 2010), pp. 19-23, ISSN 0165-2478

Endo, T. (2005). Glycans and glycan-binding proteins in brain: galectin-1-induced expression of neurotrophic factors in astrocytes. Current Drug Targets, Vol.6, No.4, (June 2005), pp. 427-436, ISSN 1389-4501

Ernsberger, U. (2009). Role of neurotrophin signalling in the differentiation of neurons from dorsal root ganglia and sympathetic ganglia. Cell and Tissue Research, Vol.336, No.3, (June 2009), pp. 349-384, ISSN 0302-766X

Fukaya, K.; Hasegawa, M.; Mashitani, T.; Kadoya, T.; Horie, H.; Hayashi, Y.; Fujisawa, H.; Tachibana, O.; Kida, S. \& Yamashita, J. (2003). Oxidized galectin-1 advances the functional recovery after peripheral nerve injury. Journal of Neuropathology $\mathcal{E}$ Experimental Neurology, Vol.62, No.2, (February 2003), pp. 162-172, ISSN 00223069

Gaudet, A.D.; Leung, M.; Poirier, F.; Kadoya, T.; Horie, H. \& Ramer, M.S. (2009). A role for galectin-1 in the immune response to peripheral nerve injury. Experimental Neurology, Vol.220, No.2, (December 2009), pp. 320-327, ISSN 0014-4886

Gavazzi, I.; Kumar, R.D.; McMahon, S.B. \& Cohen, J. (1999). Growth responses of different subpopulations of adult sensory neurons to neurotrophic factors in vitro. European Journal of Neuroscience, Vol.11, No.10, (October 1999), pp. 3405-3414, ISSN 0953-816X

Horie, H.; Bando, Y.; Chi, H. \& Takenaka, T. (1991a). NGF enhances neurite regeneration from nerve-transected terminals of young adult and aged mouse dorsal root ganglia in vitro. Neuroscience Letters, Vol.121, No.1-2, (January 1991), pp. 125-128, ISSN 0304-3940

Horie, H.; Fukuda, N. \& Bando, Y. (1991b). Hepatocytes enhance neurite regeneration and survival from transected nerve terminals. Neuroreport, Vol.2, No.9, (September 1991), pp. 521-524, ISSN 0959-4965

Horie, H.; Sakai, I.; Akahori, Y. \& Kadoya, T. (1997). IL-1 beta enhances neurite regeneration from transected-nerve terminals of adult rat DRG. Neuroreport, Vol.8, No.8, (May 1997), pp. 1955-1999, ISSN 0959-4965

Horie, H.; Inagaki, Y.; Sohma, Y.; Nozawa, R.; Okawa, K.; Hasegawa, M.; Muramatsu, N.; Kawano, H.; Horie, M.; Koyama, H.; Sakai, I.; Takeshita, K.; Kowada, Y.; Takano, M. \& Kadoya, T. (1999). Galectin-1 regulates initial axonal growth in peripheral 
nerves after axotomy. The Journal of Neuroscience, Vol.19, No.22, (November 1999), pp. 9964-9974, ISSN 0270-6474

Horie, H.; Kadoya, T.; Hikawa, N.; Sango, K.; Inoue, H.; Takeshita, K.; Asawa, R.; Hiroi, T.; Sato, M.; Yoshioka, T. \& Ishikawa, Y. (2004). Oxidized galectin-1 stimulates macrophages to promote axonal regeneration in peripheral nerves after axotomy. The Journal of Neuroscience, Vol.24, No.8, (February 2004), pp. 1873-1880, ISSN 02706474

Horie, H.; Kadoya, T.,; Sango, K. \& Hasegawa, M. (2005). Oxidized galectin-1 is an essential factor for peripheral nerve regeneration. Current Drug Targets, Vol.6, No.4, (June 2005), pp. 385-394, ISSN 1389-4501

Hughes, R.C. (1999). Secretion of the galectin family of mammalian carbohydrate-binding proteins. Biochimica et Biophysica Acta, Vol.1473, No.1, (December 1999), pp. 172-185, ISSN 0006-3002

Hynes, M.A.; Gitt, M.; Barondes, S.H.; Jessell, T.M. \& Buck, L.B. (1990). Selective expression of an endogenous lactose-binding lectin gene in subsets of central and peripheral neurons. The Journal of Neuroscience, Vol.10, No.3, (March 1990), pp. 1004-1013, ISSN 0270-6474

Imbe, H.; Okamoto, K.; Kadoya, T.; Horie, H. \& Senba, E. (2003). Galectin-1 is involved in the potentiation of neuropathic pain in the dorsal horn. Brain Research, Vol.993, No.1-2, (December 2003), pp. 72-83, ISSN 0006-8993

Inagaki, Y.; Sohma, Y.; Horie, H.; Nozawa, R. \& Kadoya, T. (2000). Oxidized galectin-1 promotes axonal regeneration in peripheral nerves but does not possess lectin properties. European Journal of Biochemistry, Vol.267, No.10, (May 2000), pp. 29552964, ISSN 0014-2956

Iwamoto, M.; Taguchi, C.; Sasaguri, K.; Kubo, K.Y.; Horie, H.; Yamamoto, T.; Onozuka, M.; Sato, S. \& Kadoya, T. (2010). The Galectin-1 level in serum as a novel marker for stress. Glycoconjugate Journal, Vol.27, No.4, (May 2010), pp. 419-425, ISSN 0282-0080

Kadoya, T. \& Horie, H. (2005). Structural and functional studies of Galectin-1: a novel axonal regneration-promoting activity for oxidized Galectin-1. Current Drug Targets, Vol.6, No.4, (June 2005), pp. 375-383, ISSN 1389-4501

Kadoya, T.; Oyanagi, K.; Kawakami, E.; Hasegawa, M.; Inagaki, Y.; Sohma, Y. \& Horie, H. (2005). Oxidized galectin-1 advances the functional recovery after peripheral nerve injury. Neuroscience Letters, Vol.380, No.3, (June 2005), pp.284-288, ISSN 0304-3940

Lekishvili, T.; Hesketh, S.; Brazier, M.W. \& Brown, D.R. (2006). Mouse galectin-1 inhibits the toxicity of glutamate by modifying NR1 NMDA receptor expression. European Journal of Neuroscience, Vol.24, No.11, (December 2006), pp. 3017-3025, ISSN 0953816X

Lindsay, R.M. (1988). Nerve growth factors (NGF, BDNF) enhance axonal regeneration but are not required for survival of adult sensory neurons. The Journal of Neuroscience, Vol.8, No.7, (July 1988), pp. 2394-2405, ISSN 0270-6474

Lindsay, R.M. \& Harmar, A.J. (1989). Nerve growth factor regulates expression of neuropeptide genes in adult sensory neurons. Nature, Vol.337, No.6205, (January 1989), pp. 362-364, ISSN 0028-0836 
Mahanthappa, N.K.; Cooper, D.N.; Barondes, S.H. \& Schwarting, G.A. (1994). Rat olfactory neurons can utilize the endogenous lectin, L-14, in a novel adhesion mechanism. Development, Vol.120, No.6, (June 1994), pp. 1373-1384, ISSN 0950-1991

Mason, M.R.; Tannemaat, M.R.; Malessy, M.J. \& Verhaagen, J. (2011). Gene therapy for the peripheral nervous system: a strategy to repair the injured nerve? Current Gene Therapy, Vol.11, No.2, (April 2011), pp. 75-89, ISSN 1566-5232

McMahon, S.B. \& Bennett D.L.H. (2000). Glial cell line-derived neurotrophic factor and nociceptive neurons, In: Molecular Basis of Pain Induction, J.N. Wood, (Ed.), 65-86, Wiley-Liss, ISBN 0-471-34607-1, New York, USA

McGraw, J.; Gaudet, A.D.; Oschipok, L.W.; Kadoya, T.; Horie, H.; Steeves, J.D.; Tetzlaff, W. \& Ramer, M.S. (2005a). Regulation of neuronal and glial galectin-1 expression by peripheral and central axotomy of rat primary afferent neurons. Experimental Neurology, Vol.195, No.1, (September 2005), pp. 103-14, ISSN 0014-4886

McGraw, J.; Gaudet, A.D.; Oschipok, L.W.; Steeves, J.D.; Poirier, F.; Tetzlaff, W. \& Ramer, M.S. (2005b). Altered primary afferent anatomy and reduced thermal sensitivity in mice lacking galectin-1. Pain, Vol.114, No.1-2, (March 2005), pp. 7-18, ISSN 03043959

Molliver, D,C,; Wright, D.E.; Leitner, M.L.; Parsadanian, A.S.; Doster, K.; Wen, D.; Yan, Q. \& Snider, W.D. (1997). IB4-binding DRG neurons switch from NGF to GDNF dependence in early postnatal life. Neuron, Vol.19, No.4, (October 1997), pp. 849861, ISSN 0896-6273

Outenreath, R.L. \& Jones, A.L. (1992). Influence of an endogenous lectin substrate on cultured dorsal root ganglion cells. Journal of Neurocytology, Vol.21, No.11, (November 1992), pp. 788-795, ISSN 0300-4864

Plachta, N.; Annaheim, C.; Bissière, S.; Lin, S.; Rüegg, M.; Hoving, S.; Müller, D.; Poirier, F.; Bibel, M. \& Barde, Y.A. (2007). Identification of a lectin causing the degeneration of neuronal processes using engineered embryonic stem cells. Nature Neuroscience, Vol.10, No.6, (June 2007), pp. 712-719, ISSN 1097-6256

Puche, A.C.; Poirier, F.; Hair, M.; Bartlett, P.F. \& Key, B. (1996). Role of galectin-1 in the developing mouse olfactory system. Developmental Biology, Vol.179, No.1, (October 1996), pp. 274-287, ISSN 0012-1606

Rabinovich, G.A.; Toscano, M.A.; Jackson, S.S. \& Vasta, G.R. (2007). Functions of cell surface galectin-glycoprotein lattices. Current Opinion in Structural Biology, Vol.17, No.5, (October 2007), pp. 513-520, ISSN 0959-440X

Regan, L.J.; Dodd, J.; Barondes, S.H. \& Jessell, T.M. (1986). Selective expression of endogenous lactose-binding lectins and lactoseries glycoconjugates in subsets of rat sensory neurons. Proceedings of the National Academy of Sciences of the United States of America, Vol.83, No.7, (April 1986), pp. 2248-2252, ISSN 2248-2252

Saito, H.; Sango, K.; Horie, H.; Ikeda, H.; Ishigatsubo, Y.; Ishikawa, Y. \& Inoue, S. (1999). Enhanced neural regeneration from transected vagus nerve terminal in diabetic mice in vitro. Neuroreport, Vol.10, No.5, (April 1999), pp. 1025-1028, ISSN 0959-4965

Saito, H.; Sango, K.; Horie, H.; Takeshita, K.; Ikeda, H.; Ishigatsubo, Y. \& Ishikawa, Y. (2002). Trachea enhances neurite regeneration from adult rat nodose ganglia in vitro. Life Sciences, Vol.70, No.16, (March 2002), pp. 1935-1946, ISSN 0024-3205 
Salt, T.E. \& Hill, R.G. (1983). Neurotransmitter candidates of somatosensory primary afferent fibers. Neuroscience, Vol.10, No.4, (December 1983), pp. 1083-1103, ISSN 0306-4522

Sango, K.; Horie, H.; Saito, H.; Ajiki, K.; Tokashiki, A.; Takeshita, K.; Ishigatsubo, Y.; Kawano, H. \& Ishikawa, Y. (2002). Diabetes is not a potent inducer of neuronal cell death in mouse sensory ganglia, but it enhances neurite regeneration in vitro. Life Sciences, Vol.71, No.20, (Otober 2002), pp. 2351-2368, ISSN 0024-3205

Sango, K.; Tokashiki, A.; Ajiki, K.; Horie, M.; Kawano, H.; Watabe, K.; Horie, H. \& Kadoya, T. (2004). Synthesis, localization and externalization of galectin-1 in mature dorsal root ganglion neurons and Schwann cells. European Journal of Neuroscience, Vol.19, No.1, (January 2004), pp. 55-64, ISSN 0953-816X

Sango, K.; Saito, H.; Takano, M.; Tokashiki, A.; Inoue, S. \& Horie, H. (2006). Cultured adult animal neurons and Schwann cells give us new insights into diabetic neuropathy. Current Diabetes Reviews, Vol.2, No.2, (May 2006), pp. 169-183, ISSN 1573-3998

Sango, K.; Yanagisawa, H. \& Takaku, S. (2007). Expression and histochemical localization of ciliary neurotrophic factor in cultured adult rat dorsal root ganglion neurons. Histochemistry and Cell Biology, Vpl.128, No.1, (July 2007), pp. 35-43, ISSN 09486143

Sango, K.; Yanagisawa, H.; Komuta, Y.; Si, Y. \& Kawano, H. (2008). Neuroprotective properties of ciliary neurotrophic factor for cultured adult rat dorsal root ganglion neurons. Histochemistry and Cell Biology, Vol.130, No.4, (October 2008), pp. 669-679, ISSN 0948-6143

Sango, K.; Yanagisawa, H.; Kawakami, E.; Takaku, S.; Ajiki, K. \& Watabe, K. (2011). Spontaneously immortalized Schwann cells from adult Fischer rat as a valuable tool for exploring neuron-Schwann cell interactions. Journal of Neuroscience Research, Vol.89, No.6, (March 2011), pp. 898-908, ISSN 0360-4012

Sasaki, T.; Hirabayashi, J.; Manya, H.; Kasai, K. \& Endo, T. (2004). Galectin-1 induces astrocyte differentiation, which leads to production of brain-derived neurotrophic factor. Glycobiology, Vol.14, No.4, (April 2004), pp. 357-363, ISSN 0959-6658

Shuto, T.; Horie, H.; Hikawa, N.; Sango, K.; Tokashiki, A.; Murata, H.; Yamamoto, I. \& Ishikawa, Y. (2001). IL-6 up-regulates CNTF mRNA expression and enhances neurite regeneration. Neuroreport, Vol.12, No.5, (April 2001), pp. 1081-1085, ISSN 0959-4965

Terenghi, G. (1999). Peripheral nerve regeneration and neurotrophic factors. Journal of Anatomy, Vol.194, Part 1, (January 1999), pp. 1-14, ISSN 0021-8782

Tracey, B.M.; Feizi, T.; Abbott, W.M.; Carruthers, R.A.; Green, B.N. \& Lawson, A.M. (1992). Subunit molecular mass assignment of 14,654 Da to the soluble beta-galactosidebinding lectin from bovine heart muscle and demonstration of intramolecular disulfide bonding associated with oxidative inactivation. The Journal of Biological Chemistry, Vol.267, No.15, (May 1992), pp. 10342-10347, ISSN 0021-9258

Watabe, K.; Fukuda, T.; Tanaka, J.; Honda, H.; Toyohara, K. \& Sakai, O. (1995). Spontaneously immortalized adult mouse Schwann cells secrete autocrine and paracrine growth-promoting activities. Journal of Neuroscience Research, Vol.41, No.2, (June 1995), pp. 279-290, ISSN 0360-4012 
Yasuda, H.; Terada, M.; Maeda, K.; Kogawa, S.; Sanada, M.; Haneda, M.; Kashiwagi, A. \& Kikkawa, R. (2003). Diabetic neuropathy and nerve regeneration. Progress in Neurobiology, Vol.69, No.4, (March 2003), pp. 229-285, ISSN 0301-0082

Zochodne, D. (2008). Neurobiology of Peripheral Nerve Regeneration, Cambridge University Press, ISBN 978-0-521-86717-7, Cambridge, UK 


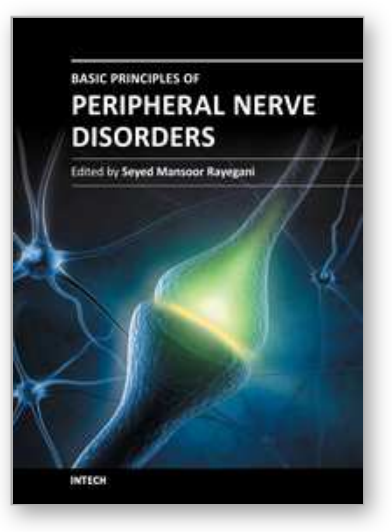

\author{
Basic Principles of Peripheral Nerve Disorders \\ Edited by Dr. Seyed Mansoor Rayegani
}

ISBN 978-953-51-0407-0

Hard cover, 278 pages

Publisher InTech

Published online 28, March, 2012

Published in print edition March, 2012

Peripheral nerve disorders are comprising one of the major clinical topics in neuromusculoskeletal disorders. Sharp nerve injuries, chronic entrapment syndromes, and peripheral neuropathic processes can be classified in this common medical topic. Different aspects of these disorders including anatomy, physiology, pathophysiology, injury mechanisms, and different diagnostic and management methods need to be addressed when discussing this topic. The goal of preparing this book was to gather such pertinent chapters to cover these aspects.

\title{
How to reference
}

In order to correctly reference this scholarly work, feel free to copy and paste the following:

Kazunori Sango, Hiroko Yanagisawa, Kazuhiko Watabe, Hidenori Horie and Toshihiko Kadoya (2012). Galectin-1 as a Multifunctional Molecule in the Peripheral Nervous System After Injury, Basic Principles of Peripheral Nerve Disorders, Dr. Seyed Mansoor Rayegani (Ed.), ISBN: 978-953-51-0407-0, InTech, Available from: http://www.intechopen.com/books/basic-principles-of-peripheral-nerve-disorders/galectin-1-as-amultifunctional-molecule-in-the-peripheral-nervous-system-after-injury

\section{INTECH}

open science | open minds

\section{InTech Europe}

University Campus STeP Ri

Slavka Krautzeka 83/A

51000 Rijeka, Croatia

Phone: +385 (51) 770447

Fax: +385 (51) 686166

www.intechopen.com

\section{InTech China}

Unit 405, Office Block, Hotel Equatorial Shanghai

No.65, Yan An Road (West), Shanghai, 200040, China

中国上海市延安西路65号上海国际贵都大饭店办公楼 405 单元

Phone: +86-21-62489820

Fax: $+86-21-62489821$ 
(C) 2012 The Author(s). Licensee IntechOpen. This is an open access article distributed under the terms of the Creative Commons Attribution 3.0 License, which permits unrestricted use, distribution, and reproduction in any medium, provided the original work is properly cited. 